\title{
Testicular Choriocarcinoma
}

National Cancer Institute

\section{Source}

National Cancer Institute. Testicular Choriocarcinoma. NCI Thesaurus. Code C7733.

A malignant germ cell tumor arising from the testis. It represents the rarest of the testicular germ cell tumors. Histologically it is characterized by the presence of syncytiotrophoblasts and cytotrophoblasts. 